\title{
Injustice and Persecution: Forced Migration of Sindhi Hindus in Pakistan
}

\author{
Abdul Hadi \\ Ph. D Student. Ankara University, Faculty of Letteres, Department of Sociology, Karargahtepe Mahallesi Atış Caddesi, \\ Polat Apartment 50/7, Postal code. 06120, Keçiören, Ankara, Turkey \\ hadijarwar@gmail.com
}

\section{Doi:10.5901/mjss.2015.v6n2s5p11}

Abstract

Sufism, secularism, pluralism, and religious tolerance are few for the unique features Sindh had always been known for around the globe. When the rest of Pakistan was devastated by sectarian genocide and targeted persecution, there was much to be learned from Sindh. People of Sindh have always been pluralistic and tolerant, but state sponsored seminaries house ethnic Punjabi or Pashtun Mullahs from Punjab and KPK provinces who target, harass and persecute Sindhi Hindus. The continued incidences of violence against the largest religious minority group Sindhi Hindus have created a sense of insecurity among them. They are subjected to kidnapping for ransom, forced abductions and conversions of their women. These trends forcing the indigenous dwellers to abandon their motherland. The aim of this study is to highlight the targeted discrimination and persecution of Sindhi Hindus which force them to abandon their own homeland Sindh. It also evaluates the underlying causes behind criminal activities and what are the possible motives of perpetrators. This study concluded that state sponsored religious seminaries that house ethnic Punjabi or Pashtun Mullahs from Punjab and KPK provinces are involved in the persecution of Sindhi Hindus. This is a conspiracy against indigenous people of Sindh to convert them into minority on their own homeland. By altering the demography of Sindh, they can undermine the political strength of Sindhis and make them defenseless to protect their natural resources, culture, language and their real and historical identity.

Keywords: Internal Colonialism; Sindhi; Hindu; Forced conversion; kidnapping for ransom; Forced Migration; Religious Extremism

\section{Historical Background}

Pakistan is not one country composed of only one Nation but is a conglomeration of socio-cultural different nationalities. The 'ethnic minorities' that basically comprise the smaller nations of Pakistan never supported the creation of Pakistan. But British imperialists decided to divide up India for strategic reasons and purposely set out to create a new state called Pakistan against the wishes of Sindh and other minority ethnic groups. After the construction of Pakistan, Sindhi, Baluch, and Pashtuns feel that they are trapped in a political set up which is run by dominant province Punjab since Punjab controls armed forces and key political institutions (Harrison, 2009).

With the emergence of Pakistan state started attempts to erase the real and historical national identity of ethnonation groups and enforced on them a new identity some time in shape of Muslim nation and other time Pakistani nation. The opening of religious seminaries and religious syllabus are few of the methods have been used by state in this regard which gave birth to the religious extremism. A Sindhi political leader GM Syed delivered a spellbinding speech at the Vienna International Peace Conference in 1952. He deplored American and British efforts to unite Muslims based on their faith which, he felt, engendered serious ramifications. He warned them that patronizing such forces would promote religious extremism and fascism.

Right from the beginning Pakistan become a theocratic state in which other religious minorities were forced to leave country to make this country purify from unholy people. But it was not much easy to erode long native Sufi tradition. However, the anti-Soviet Afghan jihad of the 1980s had a massive blowback on Pakistani Sufi culture. In that period, General Zia ul Haq a dictator introduced Islamization programs which extremely transformed the Pakistani society. His islamization programs introduced rules and regulations to make Pakistani law more into tune with the Islamic law, or at least Islamic law as understood by him and his cronies (Ispahani, 2013). Huge amount of money from Saudi Arabia and other Gulf counties spent on Madrassas/religious schools to proliferate the ideology of Wahhabism which started eroding the centuries-long native Sufi tradition of peace and harmony among different religious and sects.

When the rest of Pakistan was devastated by sectarian genocide and targeted persecution, there was much to be learned from Sindh. People of Sindh have always been pluralistic and tolerant, but state sponsored seminaries house ethnic Punjabi or Pashtun Mullahs from Punjab and KPK provinces who eliminate dissenters with impunity. There are 
number of religious extremists groups which operate in Sindh and spread the message of hatred and encourage violent jihad (Holy war) towards Sindhi Hindus.

Sindhi Hindus are increasingly subject to kidnapping for ransom. Rape, forcible and pressurized conversion to Islam have also become a matter of course for Hindus living in Sindh. As a result, thousands of Sindhi Hindus have forcedly migrated to India. Remaining Sindhi Hindus live in perpetual fear and anxiety as their lives, property and worship places are at stake. The aim of this study is to highlight the targeted discrimination and persecution of Sindhi Hindus forcing them to abandon their own homeland Sindh. It also evaluate the underlying causes behind criminal activities and what are the possible motives of perpetrators. Sindhi Hindus are persecuted in many ways but few of them which compelled them to migrate to India will be illustrated here.

\section{Persecution of Sindhi Hindus}

It was reported that the growing extremism has made Pakistan a very hostile county for Sindhi Hindus. The Sindhi Hindus raised their concerns about the abduction of girls and their forced conversion to Islam and their frequent kidnapping for ransom. But the indifferent attitude of the police and insensitive judicial system make them feel that they are unacceptable to Pakistan.

\section{Forced Conversions}

There has been an increase in Sindh, of the abduction and forced conversion to Islam of Hindu girls. The young Hindu girls were being kidnapped and forced to marry to Muslim boys and converted to Islam. The Asian Human Rights Commission documented that there are 20-25 forced conversions every month in Sindh (AHRC, 2012).

What has made the matters worse is the indifferent attitude of the police and insensitive judicial system. Police often refuse to register FIRs and in cases they do, the courts send the teenage girls to Islamic school centers or back to the kidnapper's home instead of the girls' families and women shelters. The Human Rights Commission of Pakistan (HRCP) in its report on 'Working Group on Communities Vulnerable Because Of Their Beliefs' said the courts often decided such cases against the girls' families even if the girls were of 12 or 13 years of age (HRCP, 2014). Even the Hindus who are the part of assemblies and legislation feel powerless and marginalized. "Our community can bear looting and the kidnapping of our men, but the abduction of our daughters and wives is too painful," Bhawan Das, who holds a National Assembly seat reserved for minorities, told Al Jazeera. Bherulal Balani, a former legislator, reported: "Once the girls are converted, they are then sold to other people or are forced into illegal and immoral activities" (The News, 2010).

Kidnapping for Ransom

Another major persecution facing Hindus is their kidnapping for ransom. Hindus are routinely abducted for ransom, particularly in northern part of Sindh. Hindu traders in Sindh are increasingly face extortion or abduction for ransom (USCIRF, 2011). The case studies of these incidences indicates that that a powerful syndicate of bandits and their patrons regularly abduct wealthy Hindus for ransom. In case of delay in ransom money, abductees are killed. However, there are incidences in which abductees are killed even though they paid ransom.

The exact number of kidnapping for ransom cannot be stated because many of them are not reported due to fear of the abductors killing the abductee (Siddiqa, 2012). However, there is a growing cases of abduction in recent years causing Hindus to leave their homeland. Pitnaber Sewani, a minority MPA from Sindh said "During the last two years, around 29 men from only Kandkhot (District of Sindh) area have been kidnapped" (Rehman, 2011).

Leaders of Hindu community claim that the abductions of Hindus are commonplace and abductors have been give free hand; police and other law enforcement agencies have been patronizing the abductors. A refugee told during their protest demonstration in Delhi after fledging from Pakistan that they were either targeted by gangs of criminal or harassed by the seminaries that house ethnic Punjabi or Pashtun Mullahs from Punjab and KPK provinces (Shah, 2014). The routinely kidnapping of Hindu traders for ransom has caused the anxiety among the already disadvantaged Hindus.

It shows that Punjabi and Pashtun Mullahs who run religious seminaries are involved behind the abduction and forced conversion to Islam of Sindhi Hindu girls and kidnapping for ransom for Sindhi Hindus. They are working under the patronization of government. Feeling insecure in Sindh, thousands of Sindhi Hindus are compelled to abandon their homeland Sindh.

\section{Forced Migration of Sindhi Hindus}

At the time of Partition, Hindus comprised 15 per cent of Pakistan's population. Today, one estimate puts it at 2 per cent 
while another suggests 5.5 per cent with majority of them living in Sindh (Sharma, 2012). Around 90 percent of the total Hindus population lives in Sindh.

Sindh is going through the trauma of migration and heart-broken emotions of innocent indigenous inhabitants. The fear of being forced to conversion, abduction of daughters or other women in the family and their conversion to Islam under duress, or kidnapping for ransom are some of the many reasons that have probably exhausted Hindus to seek asylum elsewhere (Siddiqa, 2012).

The Pakistani Hindu Seva, community welfare organization, estimates that while 10 Sindhi Hindu families migrated to India from Sindh every month since 2008, in the past 10 months, 400 families have left to India due to fear of safety (Bhatia, 2009). In 2009, a Times of India report put the total number of Sindhi Hindus migrating to India at 5000 (Sharma, 2012). Additionally, Pakistan's Hindu Council estimates that at least 1,000 Hindu families are now leaving Pakistan per year (WSC, undated). Other Sindhi Hindu leaders reportedly said that dozens of families were migrating to India every month. Even a Hindu Member of Sindh Assembly, after receiving threats from extremists group resigned from his seat and sought asylum in India. According a Sindhi Hindu journalist, Sindhi Hindus are abandoning their motherland because they think that they are not acceptable to Pakistani society (Rehman, 2011).

\section{Discussion}

The exodus of Sindhi Hindus has ushered in hot debate among the scholars and intellectuals. They tried to find the causes behind the persecution of Sindhi Hindus and why the perpetrators have given free hands and are not caught by law enforcement authorities?

A leading Sindhi international organization World Sindhi Congress expressed their apprehension that state sponsored religious fundamentalism is dividing Sindhi nation on the name of religion and a direct tactic to convert Sindhis into minority on their own motherland. Further it said that due to increased discrimination and violence directed towards indigenous Sindhi Hindus, including the abductions of young girls, is prompting an observed emigration of Hindus out of Pakistan (WSC, 2014). Some Sindhi scholars think that exodus of Hindus would undermine the Sindhi nationalism and freedom movement. Because with the migration of Sindhi Hindus, and inflow of other ethnic groups in Sindh will create demographic changes, converting ethnic Sindhis into permanent minority in their own historical land (Shah, 2012). A well-known columnist Venegas (2012) said that Mass migration of Hindus from Sindh is the part of conspiracy which want to convert Sindhi into minority on their own land. (Veengas, 2012).

The most important point has been raised by Word Sindhi Congress and other scholars and I concur with them that this is a conspiracy against indigenous people of Sindh to convert them in minority in their own mother land. Because with the migration of Sindhi Hindus and inflow of refuges from other countries and tribal areas along with other three provinces of Pakistan would alter the demography of Sindh.

As documents reveals that at the time of partition, Sindhi were 98 percent of the Sindh out of which 35 percent were Hindus. However, currently, there number is reduced to only 65 percent because of the inflow of refuges from Afghanistan, Bangladesh, Myanmar and Tribal Areas along with other three provinces of Pakistan. If Sindhi Hindus migration continues in this way, sooner Sindhi will be in minority on their own homeland Sindh.

There is a question why the attempts are made to alter the demography of Sindh? According to (Veengas, 2012) Mass migration will destroy Sindh's economy as Hindus are business community of Sindh and will damage the vote bank of Sindhis. Other Scholars call it a conspiracy to undermine the Sindhi Nationalism and freedom movement. Being concurred with their views, It is argued that by altering the demography of Sindh, they can undermine the political strength of Sindhis and make them defenseless to protect their natural resources, culture, language and their real and historical identity.

\section{Conclusion}

The persecution of Hindus by state sponsored religious extremists and inflow of refugees testify the claims of Sindh rights activist and scholars that this is a conspiracy against Sindhis to convert them into minority on their own homeland. Converting of Sindhi people into minority on their own homeland have been done in two ways. Firstly, harassing indigenous Sindhi Hindus to the extent that they compel to leave their homeland. Secondly, allowing the inflow of other ethnic groups in Sindh who are spreading hatred against Sindhi Hindus and damaging the Sufi culture of Sindh. By altering the demography of Sindh, they can undermine the political strength of Sindhis and make them defenseless to protect their natural resources, culture, language and their real and historical identity. 


\section{References}

Adeola, F. O. (2000). Cross-National Environmental Injustice and Human Rights Issues, A Review of Evidence in the Developing World. AHRC. (2012). Asian Human Rights Commission report.

Siddiqa, A. (2012). The Hindu Exodus, Tehelka Magazine, Vol 9, Issue 34.

Bhatia, V. (2009). Fearing Taliban, Pak Hindus take Thar Express to India, Times of India.

HRCP. (2010). State of Human rights, Human Rights Commission of Pakistan, Pp. 137.

HRCP. (2014). State of Human Rights in 2013, Published by Human Rights Commission of Pakistan, 2014.

Ispahani, F. (2013). Cleansing Pakistan of Minorities.

Rehman, Z. (2011). Hindus no more safe at home, The Friday Times, November 18-24, 2011-vol. xxiii, no. 40.

Shah, Z. (2012). Roots of Sindhi-Hindu Exodus from Pakistan.

Shah, Z. (2014). Sindhi Hindu exodus causing humanitarian red alert for India, Indus Asia Online Journal (iaoj).

Sharma, R. (2012). Hindus, Christians denied civic and religious protection.

Sornarajah (1981). Internal Colonialism and Humanitarian Intervention M. , Ga. , J. , Int'l \& Comp. , L. [Vol. 11: 1.

The News (2010). 25 Hindu girls abducted every month, claims HRCP official.

USCIRF. (2011). United States Commission on International Religious Freedom, Annual report, pp. 114.

Veengas (2012). Sindh- from Rinkle Kumari to Migration of Hindus, By Daily Ibrat.

WSC. (2014). Condemn Systematic Persecution of Indigenous Sindhi Hindus in Pakistan, World Sindhi Congress.

WSC. (Undated). Discrimination against Lesser Known Religious Minorities of Pakistan, World Sindhi Congress. 